\title{
PENGARUH FREKUENSI PENYIRAMAN AIR MENGGUNAKAN SPRINKLER TERHADAP RESPON FISIOLOGIS DAN PERTUMBUHAN SAPI PERANAKAN SIMMENTAL
}

\section{EFFECT OF WATERING FREQUENCY USING SPRINKLER ON PHYSIOLOGICAL RESPONSE AND GROWTH OF SIMMENTAL GRADE CATTLE}

\author{
Kusuma Adhianto*, Siswanto, dan Citra Nindya Kesuma \\ Jurusan Peternakan, Fakultas Pertanian, Universitas Lampung, Bandar Lampung, 35145
}

Submitted: 9 April 2015, Accepted: 15 May 2015

\section{INTISARI}

\begin{abstract}
Penelitian bertujuan untuk mengetahui pengaruh frekuensi penyiraman air terhadap respon fisiologis dan produksi sapi Peranakan Simmental. Penelitian dilaksanakan selama 45 hari dimulai pada Desember 2014 hingga Januari 2015 bertempat di kandang peternakan Koperasi Gunung Madu Plantation, Kecamatan Gunung Batin, Kabupaten Lampung Tengah. Analisis ransum dilakukan di Laboratorium Nutrisi dan Makanan Ternak (NMT), Jurusan Peternakan, Fakultas Pertanian, Universitas Lampung. Desain penelitian menggunakan Rancangan Acak Lengkap (RAL) pola searah terdiri dari: tanpa perlakuan atau kontrol (P0), frekuensi penyiraman air 1 kali (P1), dan frekuensi penyiraman air 2 kali (P2). Berdasarkan hasil penelitian yang telah dilakukan dapat disimpulkan bahwa perlakuan frekuensi penyiraman air berpengaruh secara nyata $(P<0,01)$ terhadap respon fisiologis ternak, dan berpengaruh secara nyata terhadap konsumsi dan pertumbuhan sapi Peranakan Simmental.
\end{abstract}

(Kata kunci: Produksi, Respon fisiologis, Sprinkler)

\section{ABSTRACT}

The objective of the research was to measure the effects of watering frequency using sprinkler on the physiological response and production of simmental grade cattle. Experiment was conducted during 45 days starting on December 2014 to January 2015 in Gunung Madu Plantation Cooperative farms, Gunung Batin district, Central Lampung regency. Feed analysis was carried out in the Laboratory of Animal Nutrition and Feed, Department of Animal Husbandry, Faculty of Agriculture, University of Lampung. The experimental design used in this study was performed by using a Completely Randomized Design with treatment of control (P0), frequency of watering 1 time (P1) and frequency of watering 2 times (P2). Based on the results of research, we concluded that watering frequency treatment significantly $(P<0.01)$ effected on the physiological response of Simmental grade cattle. However, treatment have not significantly effecting on consumption and growth of Simmental grade cattle.

(Key words: Physiological response, Production, Sprinkler)

\section{Pendahuluan}

Jumlah penduduk di Indonesia selalu menunjukkan peningkatan dari tahun ke tahun. Pada tahun 2014 mencapai 252,16 juta meningkat dibanding tahun 2010 sebesar 237,64 juta. Penduduk Indonesia 5 tahun terakhir ini telah meningkat dengan laju pertumbuhan sekitar 1,49\% per tahun (Badan Pusat Statistik, 2014). Jumlah penduduk yang terus meningkat menyebabkan peningkatan kebutuhan protein hewani yang berasal dari ternak. Siagian (2008) menyatakan bahwa konsumsi protein hewani yang berasal dari ternak ditargetkan mencapai 6 g/kapita/hari, namun baru tercapai sekitar 4,7 g/kapita/hari.

Sapi merupakan salah satu ternak yang memberikan kontribusi besar untuk memenuhi kebutuhan protein masyarakat Indonesia. Pengembangan peternakan sapi salah satunya harus didukung oleh peningkatan produktivitas ternak. Produktivitas ternak dipengaruhi oleh faktor genetik dan lingkungan (Purwanto et al., 1991). Salah satu faktor lingkungan yang berpengaruh terhadap produktivitas sapi adalah iklim. Produktivitas dan kondisi fisiologis sapi yang dipelihara pada iklim

\footnotetext{
* Korespondensi (corresponding author):

Telp. +62 81227972696

E-mail: kusuma.adhianto@fp.unila.ac.id
} 
tropis berbeda dengan sapi yang dipelihara pada iklim subtropis. Indonesia merupakan negara beriklim tropis dengan suhu lingkungan yang cukup tinggi yaitu $28-34^{\circ} \mathrm{C}$ pada siang hari, dan di Provinsi Lampung mencapai $23,2-33,6^{\circ} \mathrm{C}$. Suhu lingkungan di Kabupaten Lampung Tengah mencapai $23-33^{\circ} \mathrm{C}$ pada siang hari (BMKG, 2014). Sapi yang dipelihara pada suhu lingkungan yang tinggi dapat mengalami stres.

Kondisi lingkungan yang panas dapat menyebabkan cekaman pada tubuh sapi potong yang salah satunya akan berdampak pada peningkatan suhu rektal, frekuensi pernapasan, denyut jantung, dan penurunan konsumsi ransum, sehingga akan berdampak pada penurunan produksi ternak. Sapi potong yang banyak dipelihara di Provinsi Lampung merupakan sapi silangan antara sapi lokal dengan bangsa-bangsa sapi yang biasa hidup pada iklim subtropis yang memiliki suhu lingkungan lebih rendah daripada iklim tropis. Salah satu sapi silangan tersebut adalah sapi Peranakan Simmental yang merupakan hasil persilangan antara sapi Simmental jantan yang merupakan sapi subtropis dari benua Eropa dengan Peranakan Ongole (PO) betina. Sapi Peranakan Simmental pada umumnya akan mengalami cekaman panas apabila dipelihara di Indonesia sehingga potensi produksi yang baik kadang tidak muncul akibat kondisi lingkungan. Oleh karenanya diperlukan manajemen pengendalian lingkungan yang tepat agar sapi dapat berproduksi secara optimal.

Manajemen pengendalian lingkungan seperti teknik modifikasi untuk mengendalikan suhu panas perlu dilakukan untuk memberikan tingkat kenyamanan ternak, sehingga dapat menghasilkan produksi yang optimal (Collier et al., 2006). Rekayasa untuk mengurangi suhu lingkungan panas dapat dilakukan dengan penyiraman air menggunakan sprinkler ke tubuh ternak dan efektif mengurangi efek fisiologis akibat cekaman panas pada sapi (Mitlohner et al., 2001).

Ismail (2006) menyatakan bahwa perlakuan penyiraman pada sapi perah memberikan respon yang baik terhadap produktivitas ternak, tetapi belum dilaporkan pengaruhnya terhadap fisiologis dan produksi pada sapi potong. Berdasarkan kondisi tersebut, maka dilakukan penelitian untuk mengetahui pengaruh frekuensi penyiraman air terhadap respon fisiologis dan produksi sapi Peranakan Simmental.

\section{Materi dan Metode}

\section{Waktu dan tempat penelitian}

Penelitian dilaksanakan selama 45 hari dimulai pada Desember 2014 hingga Januari 2015 bertempat di kandang peternakan Koperasi Gunung Madu Plantation, Kecamatan Gunung Batin, Kabupaten Lampung Tengah. Analisis ransum dilakukan di Laboratorium Nutrisi dan Makanan Ternak (NMT), Jurusan Peternakan, Fakultas Pertanian, Universitas Lampung.

\section{Materi}

Sapi Peranakan Simmental. Sapi penggemukan yang digunakan dalam penelitian ini adalah sapi Peranakan Simmental jantan sebanyak 12 ekor. Sapisapi tersebut dipelihara oleh Koperasi Gunung Madu Plantation.

Pakan. Pakan yang diberikan selama penelitian berupa pakan komplit (complete feed), yang sudah digunakan di peternakan Koperasi PT Gunung Madu Plantation. Kandungan nutrisi ransum yang digunakan dapat dilihat pada Tabel 1. Pemberian pakan dilakukan sebanyak 3 kali, yaitu pagi, siang dan malam hari dengan jumlah pemberian sebanyak 30 kg/ekor/hari.

Air. Air dalam penelitian ini digunakan untuk konsumsi sapi dan perlakuan penyiraman pada tubuh ternak. Air yang digunakan berasal dari air tadah hujan sekitar peternakan.

\section{Alat penelitian}

Alat yang digunakan dalam penelitian terdiri atas: termometer infrared merk IR thermometer dengan ketelitian $\pm 0,3^{\circ} \mathrm{C}$ atau $0,54^{\circ} \mathrm{F}$ yang digunakan untuk mengukur suhu rektal sapi; termohigrometer yang digunakan untuk mengukur suhu dan kelembaban kandang; counter number yang digunakan sebagai alat untuk menghitung frekuensi pernafasan; stetoskop digunakan untuk mengukur denyut jantung pada sapi; stopwatch digunakan untuk mengukur frekuensi pernafasan, denyut jantung, dan waktu penyiraman air; timbangan pakan kapasitas $15 \mathrm{~kg}$ merk five goats dengan ketelitian 0,1 kg digunakan untuk menimbang pakan dan sisa pakan; sekop dan bak 
Tabel 1. Kandungan nutrisi pakan penelitian (nutrient content of research feed)

\begin{tabular}{lc}
\hline \multicolumn{1}{c}{ Komponen (component) } & Kandungan nutrisi (\%) (nutrient content (\%)) \\
\hline Bahan kering (BK) (dry matter (DM)) & 38,43 \\
Protein kasar (PK) (crude protein (CP)) & 8,15 \\
Lemak kasar (LK) (ether extract (EE)) & 5,00 \\
Serat kasar (SK) (crude fiber (CF)) & 18,83 \\
Abu (ash) & 18,30 \\
Bahan ekstrak tanpa nitrogen (BETN) (nitrogen free & \\
extract (NFE)) & 49,71 \\
\hline
\end{tabular}

digunakan untuk distribusi pakan; sapu lidi digunakan untuk membersihkan kandang; timbangan sapi merk Sonic A12E kapasitas $2000 \mathrm{~kg}$ dengan ketelitian 0,5 kg; alat sprinkler digunakan untuk melakukan penyiraman pada tubuh sapi; selang dengan panjang $20 \mathrm{~m}$ digunakan untuk membantu proses penyiraman air ke tubuh sapi dan pada proses cleaning; alat tulis dan kertas digunakan untuk mencatat data yang diperoleh.

\section{Metode penelitian}

Desain eksperimental dalam penelitian ini menggunakan Rancangan Acak Lengkap (RAL) yang terdiri dari 3 perlakuan dan 4 ulangan pada setiap perlakuan, terdiri dari: tanpa perlakuan atau kontrol (P0), frekuensi penyiraman air 1 kali (P1), sapi mendapat perlakuan penyiraman dengan air satu kali selama 1 jam pada pukul 13.00-14.00 WIB, frekuensi penyiraman air 2 kali (P2), sapi mendapat perlakuan penyiraman air dua kali selama 2 jam yaitu pada pukul 10.30-11.30 WIB dan 13.00-14.00 WIB. Penyiraman dilakukan dengan menggunakan alat penyiram (sprinkler) yang diletakkan di atap kandang. Mulut nozzle sprinkler menghadap ke bawah.

\section{Peubah yang diamati}

Peubah yang diamati adalah suhu tubuh, frekuensi pernafasan, frekuensi denyut jantung, konsumsi pakan, dan pertambahan bobot badan harian $(\mathrm{PBBH})$.

Suhu tubuh diukur dengan menggunakan thermometer infrared (digital) yang ditempelkan di permukaan dahi, mata ataupun hidung ternak sapi. Pada awal mula kondisi thermometer infrared yang akan dipakai untuk mengukur suhu harus dalam keadaan nol.

Frekuensi pernafasan dihitung menggunakan counter number dengan cara melihat kembang kempis perut atau suara dari pernafasan yang timbul pada sapi selama 1 menit.

Frekuensi denyut jantung diukur pada rongga dada menggunakan stetoskop (Kelly, 1984) atau memeriksa ekor bagian tengah setiap menitnya (Sukarli, 1995). Pengamatan respon fisiologis pada sapi Peranakan Simmental dilakukan setiap satu minggu sekali yaitu pada pukul 08.00, 10.00, 12.00, 14.00 dan 16.00 WIB.

Konsumsi pakan diperoleh dengan cara menghitung jumlah pakan yang diberikan dikurangi dengan pakan sisa setiap hari. Konsumsi pakan harian dihitung berdasarkan bahan kering (BK).

Pertambahan bobot badan harian (PBBH) dalam satuan $\mathrm{kg}$, dihitung berdasarkan selisih bobot badan akhir dan bobot badan awal dibagi dengan lama pengamatan.

\section{Prosedur penelitian}

Proses adaptasi ternak terhadap lingkungan mikro kandang dilakukan selama 10 hari, selanjutnya setelah sapi terbiasa dengan kondisi lingkungan maka dimulai proses pengamatan. Rutinitas yang dilakukan selama penelitian adalah sebagai berikut: perawatan ternak dan pembersihan kandang dilakukan pada pukul 07.00-09.00 WIB; pengukuran suhu dan kelembaban relatif kandang; pemberian pakan sebanyak 3 kali dan minum secara ad libitum; pengukuran parameter respon fisiologis ternak, meliputi pengukuran suhu rektal, frekuensi pernafasan, dan denyut jantung setiap 1 minggu sekali.

Data hasil penelitian dianalisis menggunakan sidik ragam (ANOVA) dengan taraf nyata $5 \%$ dan atau $1 \%$. Jika hasil perhitungan menunjukkan pengaruh yang nyata, maka dilanjutkan dengan uji beda nyata terkecil (BNT) pada taraf nyata $5 \%$ dan atau $1 \%$ (Steel dan Torrie, 1991). 


\section{Hasil dan Pembahasan}

\section{Kondisi iklim mikro lokasi penelitian}

Kondisi iklim mikro lokasi penelitian di kandang peternakan PT. Gunung Madu Plantation berada pada kisaran suhu lingkungan kandang $25-31,5^{\circ} \mathrm{C}$ dengan rerata $28,96^{\circ} \mathrm{C}$, sedangkan kelembaban relatif berkisar antara $70-76 \%$ dengan rerata $73 \%$. Rerata kondisi iklim mikro dapat dilihat pada Tabel 2.

Webster dan Wilson (1980) menyatakan bahwa sapi potong membutuhkan comfort zone, yaitu temperatur lingkungan yang nyaman sehingga mendukung kelancaran fungsi proses fisiologis ternak. Sebagai hasil silangan antara sapi dari daerah sedang dengan sapi daerah tropis, maka diduga comfort zone (CZ) untuk sapi Peranakan Simmental adalah $17-28^{\circ} \mathrm{C}$ (Aryogi et al., 2005). Hal ini berarti suhu dan kelembaban udara penelitian secara fisiologis tidak sesuai dengan kondisi lingkungan yang nyaman bagi sapi Peranakan Simmental dan berpotensi menyebabkan cekaman panas.

\section{Pengaruh perlakuan terhadap respon fisiologis sapi Peranakan Simmental}

Suhu tubuh adalah hasil dari dua proses yaitu panas yang diterima dan panas yang dilepaskan. Panas terutama dihasilkan oleh tubuh sebagai hasil aktivitas metabolisme dan dilepaskan dari tubuh secara konduksi, konveksi, radiasi dan evaporasi melalui kulit dan saluran pernafasan (Ewing, 1999). Hasil pengamatan respon fisiologis sapi Peranakan Simmental selama penelitian tertera pada Tabel 3 . Rerata kisaran suhu tubuh sapi Peranakan Simmental ini masih berada dalam kisaran suhu tubuh normal seperti yang dikemukakan Williamson dan Payne (1993) bahwa kisaran suhu tubuh normal pada jenis ternak mamalia adalah $37-39^{\circ} \mathrm{C}$ dan mengalami fluktuasi harian yaitu sekitar 1$2^{\circ} \mathrm{C}$, mencapai minimum di pagi hari dan maksimum pada siang hari.

Hasil analisis ragam menunjukkan bahwa P2 berpengaruh sangat nyata $(P<0,01)$ terhadap suhu tubuh sapi Peranakan Simmental dibandingkan dengan P0 dan P1. Perbedaan suhu tubuh sapi Peranakan Simmental pada P2 dibandingkan dengan P0 dan P1 diduga akibat air yang disiramkan ke tubuh sapi Peranakan Simmental menyerap panas tubuh ternak, sehingga beban panas yang dimiliki ternak dapat berkurang. Perlakuan penyiraman membantu ternak mengurangi cekaman panas melalui konduksi, konveksi, dan evaporasi kulit. Pelepasan panas dilakukan secara konduksi saat air disiramkan ke tubuh ternak terjadi proses transfer panas dari tubuh ke media air yang suhunya lebih dingin pada lapisan tipis yang berada disekitar kulit (Sukarli, 1995; Gaughan et al., 2004; Kendall et al., 2007).

Ensminger (1971) menyatakan bahwa frekuensi pernafasan sapi pada kondisi normal berkisar 10-30 kali/menit, sedangkan menurut Akoso (1996), frekuensi pernafasan

Tabel 2. Rerata suhu udara dan kelembaban di kandang Peternakan PT. Gunung Madu Plantation (average temperature and humidity in PT. Gunung Madu Plantation Farm)

\begin{tabular}{ccc}
\hline \hline Minggu (week) & Suhu $\left({ }^{\circ} \mathrm{C}\right)\left(\right.$ temperature $\left.\left({ }^{\circ} \mathrm{C}\right)\right)$ & Kelembaban $(\%)$ (humidity (\%)) \\
\hline 1 & $29,03 \pm 1,65$ & $70,14 \pm 1,94$ \\
2 & $29,38 \pm 1,91$ & $73,14 \pm 2,84$ \\
3 & $28,74 \pm 1,31$ & $73,45 \pm 2,96$ \\
4 & $28,69 \pm 1,48$ & $75,27 \pm 1,92$ \\
Rerata (average) & $28,96 \pm 0,26$ & $73,00 \pm 0,56$ \\
\hline
\end{tabular}

Tabel 3. Rerata respon fisiologis sapi Peranakan Simmental (average of physiological responses of Simmental grade cattle)

\begin{tabular}{lccc}
\hline \hline \multirow{2}{*}{ Peubah (variable) } & \multicolumn{3}{c}{ Perlakuan (treatment) } \\
\cline { 2 - 4 } & $\mathrm{P} 0$ & $\mathrm{P} 1$ & $\mathrm{P} 2$ \\
\hline Suhu tubuh (body temperature) & $38,28 \pm 0,06^{\mathrm{a}}$ & $38,20 \pm 0,03^{\mathrm{a}}$ & $38,02 \pm 0,05^{\mathrm{b}}$ \\
Frekuensi pernafasan (respiratory rate) & $21,14 \pm 0,81^{\mathrm{a}}$ & $19,31 \pm 0,41^{\mathrm{b}}$ & $15,63 \pm 0,53^{\mathrm{c}}$ \\
Denyut jantung (heart rate) & $81,05 \pm 1,48^{\mathrm{a}}$ & $79,78 \pm 0,77^{\mathrm{ab}}$ & $78,35 \pm 1,71^{\mathrm{b}}$ \\
\hline a,b,c Superskrip yang berbeda pada baris yang sama menunjukkan perbedaan yang sangat nyata (P<0,01) (different \\
superscripts at the same row indicate significant differences $(P<0.01))$. \\
P0: tanpa perlakuan (control), P1: frekuensi penyiraman air 1 kali (frequency of watering 1 times), P2: frekuensi \\
penyiraman air 2 kali (frequency of watering 2 times).
\end{tabular}


pada sapi dewasa berkisar antara 12-16 kali setiap menit. Pada Tabel 3 dapat dilihat bahwa rerata frekuensi pernafasan sapi Peranakan Simmental P1 dan P2 lebih rendah daripada $\mathrm{PO}$.

Hasil analisis ragam menunjukkan bahwa perlakuan penyiraman air ke tubuh sapi Peranakan Simmental berpengaruh sangat nyata $(P<0,01)$ terhadap frekuensi pernafasan. Hasil ini memperlihatkan bahwa P2 lebih baik dalam menurunan frekuensi pernapasan dibandingkan dengan perlakuan P0 dan P1. Hal ini sejalan dengan hasil penelitian Akbar (2008) yang melaporkan bahwa penyiraman air selama 15 menit pada siang hari dengan frekuensi 10 kali untuk sapi perah pasca melahirkan menunjukkan perbedaan yang nyata $(P<0,05)$ pada rendahnya frekuensi pernafasan dibandingkan dengan sapi yang diberi perlakuan tanpa penyiraman. Tingginya temperatur lingkungan mengakibatkan frekuensi pernafasan pada perlakuan P0 dan P1 lebih tinggi dibandingkan perlakuan P2. Suhu dan kelembaban udara yang tinggi akan menyebabkan kenaikan frekuensi pernafasan guna menyesuaikan diri dengan lingkungan (Mariyono et al., 1993) dan juga meningkatkan temperatur tubuh (Muller dan Botha, 1994).

Denyut jantung menurut Frandson (1992), merupakan urutan peristiwa yang terjadi secara kontinyu pada jantung, berupa gerakan diastole (relaksasi) dan gerakan sistole (kontraksi). Hasil ini menunjukkan bahwa pada kondisi lingkungan tertentu ternak mengalami cekaman panas, karena kisaran normal frekuensi denyut jantung sapi menurut Kelly (1984) adalah 55-80 kali per menit, sedangkan menurut Ensminger (1971) denyut jantung normal sapi adalah 60-70 kali per menit.

Hasil analisis ragam menunjukkan bahwa perlakuan P2 dibandingkan dengan $\mathrm{P} 0$ dan $\mathrm{P} 1$ berpengaruh nyata $(\mathrm{P}<0,05)$ pada uji beda nyata terkecil terhadap frekuensi denyut jantung sapi Peranakan Simmental (Tabel 3). Hal ini didukung oleh pendapat Ismail (2006) yang menyatakan bahwa perlakuan penyiraman air pada sapi Fries Holland dara selama 15 menit pada saat suhu udara berada pada titik puncak dapat menurunkan suhu rektal, frekuensi laju pernafasan, dan frekuensi denyut jantung.

Tingginya frekuensi denyut jantung pada perlakuan P0 dan P1 dibandingkan dengan P2 diakibatkan karena ternak mengalami perubahan baik secara eksternal maupun internal yang mengakibatkan cekaman. Perubahan secara eksternal yaitu lingkungan yang mencapai suhu dan kelembaban puncak pada $31,15^{\circ} \mathrm{C}$ dan $70,75 \%$ pada pukul 13.00 WIB, sedangkan perubahan internal berupa peningkatan panas tubuh yang terlihat dengan peningkatan suhu rektal dan frekuensi pernafasan. Hal ini didukung oleh pendapat Esmay dan Dixon (1986) yang menyatakan bila terjadi cekaman panas akibat temperatur lingkungan yang cukup tinggi maka akan menyebabkan frekuensi denyut jantung ternak akan meningkat. Hal ini berhubungan dengan peningkatan frekuensi respirasi yang menyebabkan meningkatnya aktivitas otototot respirasi, sehingga mempercepat pemompaan darah ke permukaan tubuh dan selanjutnya akan terjadi pelepasan panas tubuh.

Penurunan denyut jantung yang rendah terjadi pada perlakuan $\mathrm{P} 2$. Hal ini dikarenakan perlakuan frekuensi penyiraman air 2 kali efektif dalam membuang panas yang berada di sekitar kulit. Hilangnya panas ini selanjutnya diterjemahkan oleh sel-sel syaraf di kulit sebagai umpan balik negatif untuk mengurangi laju denyut jantung agar panas yang dibuang ke lingkungan tidak berlebihan dan suhu tubuh tetap konstan.

Hasil analisis ragam menunjukkan bahwa perlakuan frekuensi penyiraman air ke tubuh sapi Peranakan Simmental berpengaruh tidak nyata terhadap konsumsi BK

Tabel 4. Rerata konsumsi dan PBBH sapi Peranakan Simmental (average of intakes and ADG of Simmental grade cattle)

\begin{tabular}{|c|c|c|c|}
\hline \multirow{2}{*}{ Peubah (variable) } & \multicolumn{3}{|c|}{ Perlakuan (treatment) } \\
\hline & P 0 & P 1 & P2 \\
\hline Konsumsi (kg BK) (intake $(\mathrm{kg} D M))^{\mathrm{ns}}$ & $9,41 \pm 0,71$ & $9,78 \pm 0,34$ & $10,12 \pm 0,25$ \\
\hline PBBH (kg/hari) $(A D G(k g / d a y))^{n s}$ & $0,40 \pm 0,16$ & $0,38 \pm 0,22$ & $0,54 \pm 0,30$ \\
\hline
\end{tabular}


dan PBBH sapi Peranakan Simmental. Cekaman panas akibat kondisi lingkungan hidup yang tidak nyaman bagi sapi Peranakan Simmental akan mempengaruhi kondisi fisiologis dan berdampak pada menurunnya konsumsi ransum sapi Peranakan Simmental, hal ini dilakukan untuk mempertahankan temperatur tubuhnya agar tetap dalam kondisi normal. Parakkasi (1999) menyatakan bahwa pada temperatur di bawah optimum, efisiensi menurun karena ternak lebih banyak makan guna mempertahankan temperatur tubuh yang normal. Sebaliknya, pada temperatur di atas optimum ternak akan menurunkan tingkat konsumsinya guna mengurangi temperatur tubuh.

Kebutuhan konsumsi BK adalah sebesar $12,52 \mathrm{~kg}$ jika dihitung berdasarkan $3 \%$ bobot tubuh (rerata bobot tubuh 417,25 $\mathrm{kg}$ ), konsumsi BK tidak terpenuhi (Tabel 4) karena pakan yang diberikan ke ternak tidak habis dikonsumsi. Hal ini diduga akibat stres panas yang dialami ternak sehingga mempengaruhi konsumsi ransum ternak yang berdampak pada tidak tercapainya $\mathrm{PBBH}$ yang maksimum. Cekaman panas pada ternak dapat berpengaruh pada potensi genetik, penampilan reproduksi dan produksi, dan efisiensi ekonomi (Buffington et al., 1981; Kadzere et al., 2002). Lebih lanjut, peningkatan temperatur tubuh dapat menurunkan konsumsi BK, mempengaruhi absorbsi hasil metabolisme, dan distribusi nutrien dalam tubuh (Rhoads et al., 2009; West et al., 2003).

\section{Kesimpulan}

Berdasarkan hasil penelitian yang telah dilakukan dapat disimpulkan perlakuan frekuensi penyiraman air berpengaruh terhadap respon fisiologis ternak, akan tetapi belum memberi pengaruh yang nyata terhadap konsumsi dan pertumbuhan sapi Peranakan Simmental.

\section{Daftar Pustaka}

Akbar, J. 2008. Ekspresi berahi ternak sapi perah pasca melahirkan dengan dan tanpa pemberian pendingin. Skripsi. Fakultas Peternakan, Universitas Hasanudin, Makasar.

Akoso, B. T. 1996. Kesehatan Sapi : Panduan bagi Petugas Teknis, Penyuluh, dan Peternak. Kanisius, Yogyakarta.
Aryogi, Sumadi, dan W. Hardjosubroto. 2005. Performans Sapi Silangan Peranakan Ongole di Dataran Rendah (studi kasus di kecamatan Kota Anyar Kabupaten Probolinggo Jawa Timur). Seminar Nasional Teknologi Peternakan dan Veteriner, Yogyakarta.

Badan Pusat Statistik. 2014. Proyeksi Penduduk Indonesia (Indonesia Population Projection) 2010-2035. http://www.bps.go.id/index.php/publika si/16. Diakses pada 30 Maret 2015.

Badan Meteorologi Klimatologi dan Geofisika (BMKG). 2014. http://meteo.bmkg. go.id/prakiraan/propinsi/10. Diakses pada 19 Oktober 2014.

Buffington, D. E., A. Collazo-Arocho, G. H. Canton, D. Pitt, W. W. Thatcher and R. J. Collier. 1981. Black globe-humidity index (BGHI) as comfort equation for dairy cows. Trans. Am. Soc. Agric. Eng. 24: 711-714.

Collier, R. J., G. E. Dahl and M. J. VanBaale. 2006. Major advances associated with environmental effects on dairy cattle. J. Dairy Sci. 89: 1244-1253.

Ensminger, M. E. 1971. Dairy Cattle Science. Interstate Publisher Inc., Illinois.

Esmay, M. L. and J. E. Dixon. 1986. Environmental Control for Agricultural Building. AVI Publishing Company Inc., Connecticut.

Ewing, S. A., D. C. J. R Lay and E. V. Borell. 1999. Farm Animal Well Being. Stress Physiology, Animal Behavior and Environmental Design. Prentice-Hall, Inc. New Jersey.

Frandson, R. D. 1992. Anatomi dan Fisiologi Ternak. Diterjemahkan oleh: Srigandono, B. dan K. Praseno. Gadjah Mada Press, Yogyakarta.

Gaughan, J. B., M. S. Davis and T. L. Mader. 2004. Wetting and the physiological responses of grain-fed cattle in a heated environment. Aust. J. Agric. Res. 55: 253-260.

Ismail, M. 2006. Pengaruh penyiraman dan penganginan terhadap respon termoregulasi dan tingkat konsumsi akan sapi Fries Holland dara. Skripsi Program Studi Teknologi Produksi Ternak, Fakultas Peternakan, Institut Pertanian Bogor, Bogor.

Kadzere, C. T., M. R. Murphy, N. Silanikove and E. Maltz. 2002. Heat stress in lactating dairy cows: A review. Livest. Prod. Sci. 77: 59-91. 
Kelly, W. R. 1984. Veterinary Clinical Diagnosis. Bailliere, London.

Kendall, P. E., G. A. Verkerk, J. R. Webster and C. B. Tucker. 2007. Sprinklers and shade cool cows and reduce insectavoidance behavior in pasture-based dairy systems. J. Dairy Sci. 90: 36713680.

Mariyono, Ma'sum, Umiyasih, dan Yusran. 1993. Eksistensi sapi perah induk berkemampuan produksi tinggi dalam usaha peternakan rakyat. Jurnal IImiah Penelitian Ternak Grati, Sub Balai Penelitian Grati 3: 2.

Mitlohner, F. M., J. L. Morrow-Tesch, S. C. Wilson, J. W. Dailey and J. J. McGlone. 2001. Behavioral sampling techniques for feedlot cattle. J. Anim. Sci. 79: 1189-1193.

Muller, C. J. C. and J. A. Botha. 1994. Effect of shade on various parameters of Friesian cows in a Mediterranean climate in South Africa: 2. Physiological responses. S. Afr. J. Anim. Sci. 24: 56-60.

Parakkasi, A. 1999. Ilmu Nutrisi dan Makanan Ternak Ruminan. UI Press, Jakarta.

Purwanto, B. P., M. Fujita, M. Nishibori and S. Yamamoto. 1991. Effect of Environmental Temperature and Feed Intake On Plasma Concentration Of Thyroid Hormones In Dairy Heifers. Asian-Aust. J. Anim. Sci. 4: 293-298.
Rhoads, M. L., R. P. Rhoads, M. J. VanBaale, R. J. Collier, S. R. Sanders, W. J. Weber, B. A. Crooker and L. H. Baumgard. 2009. Effects of heat stress and plane of nutrition on lactating Holstein cows: I. Production, metabolism, and aspects of circulating somatotropin. J. Dairy Sci. 92: 19861997.

Siagian, V. 2008. Peningkatan Protein Hewani untuk Ketahan Pangan. Harian Bisnis Indonesia, Sumatera Selatan.

Sukarli. 1995. Pengaruh volume air yang digunakan untuk penyemprotan pada tubuh terhadap respon thermoregulasi sapi Friesian Holland dara. Skripsi Fakultas Peternakan, Institut Pertanian Bogor, Bogor.

Steel, R. G. D. and J. H. Torrie. 1991. Prinsip dan Prosedur Statistik Suatu Pendekatan Biometrik. PT. Gramedia Pustaka Utama, Jakarta.

West, J. W., B. G. Mullinix and J. K. Bernard. 2003. Effects of hot, humid weather on milk temperature, dry matter intake, and milk yield of lactating dairy cows J. Dairy Sci. 86: 232-242.

Webster, C. C. and P. N. Wilson. 1980. Agriculture in Tropics. The English Language Book Society and Longman Group, London.

Williamson, G. dan W. J. A. Payne. 1993. Pengantar Peternakan di Daerah Tropis. Terjemahan: SGN D. Darmadja. Gadjah Mada Press, Yogyakarta. 